\title{
It's time to get to the root of things
}

\author{
Joseph S. Coselli, MD
}

\footnotetext{
From the Division of Cardiothoracic Surgery, Michael E. DeBakey Department of Surgery, Baylor College of Medicine; Department of Cardiovascular Surgery, Texas Heart Institute; and CHI St. Luke's Health-Baylor St. Luke's Medical Center, Houston, Tex.

This work received no external funding.

Disclosures: Dr Coselli serves as principal investigator for clinical trials conducted by Edwards Lifesciences and Medtronic, Inc, and as a consultant for Vascutek Ltd, a Terumo Company, St Jude Medical, Inc, and Medtronic, Inc.

Author has nothing to disclose with regard to commercial support.

Received for publication Sept 9, 2015; accepted for publication Sept 11, 2015; available ahead of print Oct $15,2015$.

Address for reprints: Joseph S. Coselli, MD, One Baylor Plaza, BCM 390, Houston, TX 77030 (E-mail: jcoselli@ bcm.edu).

J Thorac Cardiovasc Surg 2016;151:291-3

$0022-5223 / \$ 36.00$

Copyright $(2) 2016$ by The American Association for Thoracic Surgery

http://dx.doi.org/10.1016/j.jtcvs.2015.09.054
}

Marfan syndrome (MFS) is a connective tissue disorder that has far-reaching effects on the skeletal, ocular, and cardiovascular systems. It results from autosomal dominant mutations in the gene that encodes fibrillin-1. The signature manifestation of cardiovascular pathology in MFS is a grossly dilated aortic root, which commonly results in aneurysm, aortic valve regurgitation, and an increased risk of dissection, rupture, and death; hence, the root is the source of all evil affecting patients with MFS.

There are 2 competing approaches to aortic root replacement (ARR) in patients with MFS: valve-replacing (VR) and valve-sparing (VS). Because of the discovery of late complications, both approaches have undergone several iterations over the past 40 years.

The original VR approach for comprehensive ARR was introduced by Bentall and De Bono ${ }^{1}$ in 1968, using a Teflon graft and Starr valve in a 33-year-old man with presumed MFS. Two decades later, Kouchoukos et $\mathrm{al}^{2}$ modified this approach by mobilizing the coronary arteries on buttons of tissue, reducing the risk of early bleeding and late pseudoaneurysm. This approach allowed for a tension-free reattachment of the coronary arteries, and with the addition of sealed graft material that greatly reduced porosity, it made wrapping the graft with the residual aortic wall unnecessary. VRARR is typically dependent on following a lifelong regimen of anticoagulation; this limitation created interest in developing an alternate approach, because patients with MFS undergoing this repair are typically in their middle to late $30 \mathrm{~s}$.

Yacoub $^{3}$ introduced the remodeling technique so as to conserve the aortic valve. Here, the aortic valve was detached from the aneurysmal sinuses of Valsalva, and its remnants were directly sutured to a complementary-shaped scalloped graft; however, this approach tended to leave the annulus unsupported and prone to dilatation over time, and often resulted in late aortic valve regurgitation and

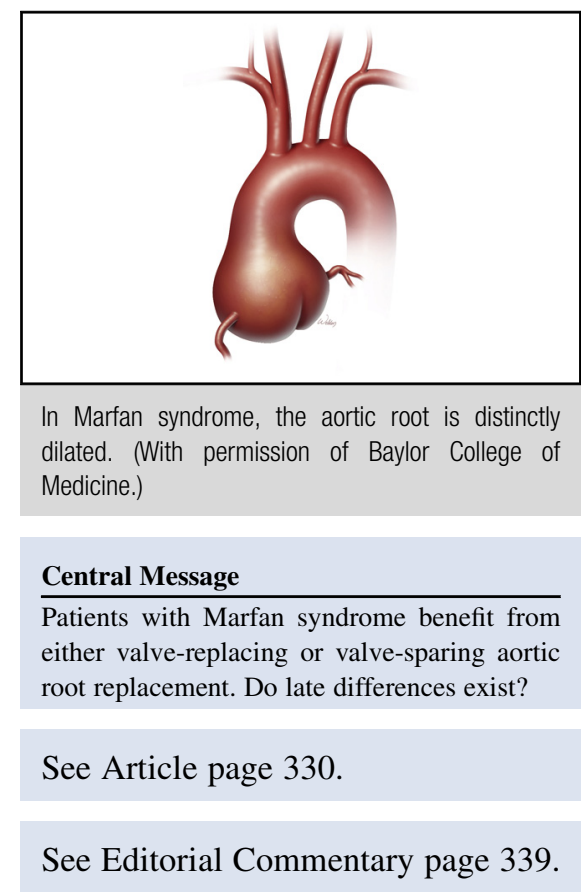

subsequent need for reoperation. ${ }^{4}$ Several VS iterations by David and others ${ }^{5-8}$ have resulted in reimplantation approaches using straight grafts as well as grafts that mimic the sinuses of Valsalva. Contemporary strategies stabilize the aortic valve annulus as the graft is fitted around the residual aortic valve, which is then sutured both around and external to the annulus and to the valve cusps within. In patients with MFS, the durability of VS approaches is inherently concerning because of potentially compromised aortic valve tissue.

Approaching the end of the 20th century, Vince Gott and others ${ }^{9}$ published what could be considered at the time nearly the entirety of surgical experience in ARR in patients with MFS. Ten centers of aortic expertise, including my own, contributed data regarding such repair. The report by Gott et $\mathrm{al}^{9}$ included repairs from October 1968 to March 1996; this experience began literally moments after Bentall and De Bono ${ }^{1}$ described their approach to repair. The report was based on ARR in 675 patients with MFS who underwent $604(89 \%)$ VRARR, $21(3 \%)$ homograft repairs, and $50(7 \%)$ VSARR. With similarly low rates of operative death, there were few differences in early outcomes between VRARR and VSARR cohorts. However, late outcomes showed greater rates of endocarditis and thromboembolism in the VRARR cohort (the latter, a consequence of lifelong anticoagulation regimens) and 
increased rates of developing greater than mild aortic valve regurgitation in the VSARR cohort. The benefit of ARR in patients with MFS was clear: with little risk of operative death $(3 \%)$, prophylactic repair dramatically changed the prognosis of patients living with MFS from having a terminal sentence to a survivable condition. The article established VRARR as a durable repair method and the procedure of choice for most surgeons, and notes that "the role of valve-sparing procedures in patients with Marfan's syndrome remains unclear."

What have we learned about ARR in patients with MFS in the 21st century? Cameron et $\mathrm{al}^{4}$ described an emerging shift in approach to repair; nearly $90 \%$ of their most recent patients with MFS had requested VSARR. In this report of 372 ARRs, the results of $269(72 \%)$ VRARRs were contrasted against $85(23 \%)$ VSARRs. Both groups had a remarkably low risk of operative death $(<1 \%)$. Regarding late events, there were substantially more thromboembolic events and endocarditis in the VR cohort and more aortic valve regurgitation (greater than mild) in the VS cohort (most of these were Yacoub remodeling iterations). Of note, Cameron et $\mathrm{al}^{4}$ revealed the disappointing results of biologic VR variants, which appeared to be even less durable than VS approaches. However, Cameron et $\mathrm{al}^{4}$ note that the long-term durability of VSARR (ie, that beyond 10 years) was still unknown and "its role vis-à-vis the Bentall procedure must await further follow-up."

In 2005, an international registry (Aortic Valve Operative Outcomes in Marfan Patients [AVOOMP]) was formed to prospectively study clinical outcomes in patients with MFS after ARR using either VR (mechanical or biological composite valve graft, homograft, or porcine root) or VS (reimplantation, remodeling, or Florida sleeve) techniques. The study was designed as a prospective registry and not a randomized trial; the choice of repair was decided by surgeon, patient, and pathology. In 2009, AVOOMP $^{10}$ reported early outcomes regarding 151 ARRs in patients with MFS; 46 patients $(30 \%)$ underwent VRARR repair and 105 $(70 \%)$ underwent VSARR. In the VSARR cohort, 22 $(21 \%)$ patients underwent direct cusp repair or shortening of the free margin or both. There were no operative deaths or stroke in either group, few complications in general, and negligible difference in complication rates between groups. The overall impression of this report was that the type of ARR had no impact on early outcomes, despite the significantly longer durations of cardiopulmonary bypass, aortic crossclamp, and surgery in the VSARR cohort. These findings are supported by a recent report from the Society of Thoracic Surgeons database ${ }^{11}$ describing patients with and without MFS, comparing 1918 (14\%) VSARR with 11,825 (86\%) VRARR; despite the VS cohort having substantially greater durations of aortic crossclamp and surgery than the VR cohort, the VS cohort had more than half the rate of operative mortality ( $1.9 \%$ vs $4.9 \%)$.
Recently, early and 1-year outcomes were published regarding 316 patients with MFS who are now enrolled in AVOOMP $^{12} ; 77(24 \%)$ patients underwent VRARR and $239(76 \%)$ patients underwent VSARR. Although there are clearly more VS than VR root procedures being performed, a tendency toward less complex preoperative scenarios in VS repair was observed. There were significantly more cases of acute and chronic aortic dissection, prior cardiovascular surgery, emergent or urgent repair, and concomitant mitral valve replacement in the VR cohort. This could be due to the impression that VSARR is more technically complicated than VRARR to perform (and thus, in emergent situations VRARR is typically preferred) or that in certain situations (ie, very large aneurysms or poor-quality valve cusps that are overstretched and thinned out or have very large stress fenestrations) pathology generally dictates VRARR. Although there were similar rates of operative mortality ( 1 in each group), at 1 year there has been a concerning number of VS patients $(7 \%)$ with greater than mild aortic valve regurgitation, highlighting previous concerns of durability.

Notably, few meta-analyses comparing VR and VS approaches to aortic root repair in patients with MFS exist. In 2011, Benedetto et $\mathrm{al}^{13}$ examined 530 studies; 11 retrospective studies met criteria for analysis. The authors found no difference in rates of postoperative valve complications or endocarditis; however, thromboembolism was increased in VRARR, and aortic valve reintervention was increased in VSARR. In 2014, Hu et al ${ }^{14}$ examined 875 reports; 6 observational comparative studies met criteria for analysis. VSARR was associated with reduced thromboembolic events and endocarditis as compared with VRARR. No difference was found in rates of reoperation despite substantial levels of VSARRs developing moderate-to-severe aortic regurgitation: reoperation ranged from as low as $0 \%$ (David reimplantation approaches) to as high as $24 \%$ (Yacoub remodeling approaches).

Nearly all contemporary series of VSARR in patients with MFS have excellent early outcomes (early mortality ranging from $0 \%-2 \%$ ), which suggests the primary aspects of VSARR are replicable. ${ }^{15-20}$ Of interest, David ${ }^{6,8}$ applies his namesake approach widely; of 149 patients with MFS undergoing ARR, David ${ }^{6}$ was able to perform a VS approach in $146(98 \%)$. Like other centers, death following VSARR is rare $(<1 \%)$; however, the estimated rate of greater than mild aortic valve regurgitation did not reach concerning levels until 15 years after repair $(7.9 \% \pm 3.3 \%$ at 15 years $) .{ }^{6}$ How is David able to achieve these results? It is quite possible that the painstaking repairs to the aortic valve itself help delay the development of late aortic regurgitation; nearly half of all his cases underwent plication repair to shorten the free margin of prolapsing cusps and/or, in the presence of stress fenestrations, direct cusp repair weaving a double layer of polytetrafluoroethylene suture along the free margin. 
Notably, in the era of Gott et al, ${ }^{9}$ more than half of all ARRs were performed at an aortic root diameter above $6 \mathrm{~cm}$. By establishing that ARR could be safely replicated at multiple centers, performed with a low early mortality rate, and prolonged life in patients with MFS, a shift to prophylactic repair at lower diameters was made possible. In the first AVOOMP publication, ${ }^{10}$ the median aortic root diameter was $5 \mathrm{~cm}$, with no significant difference between VR and VS cohorts. Increased awareness of MFS and decreasing diameter-based thresholds of repair may have contributed to the improved, lower rates of early mortality in contemporary ARR. Lingering concerns include deciphering the superiority of technique from a multitude of VSARR approaches that have been used in the past decade. In particular, this includes the variable techniques for replicating the sinuses of Valsalva: more data are needed before the ideal replication is identified. Although there remain unanswered questions regarding optimal ARR in patients with MFS, we are closer to getting to the root of the problem than in decades past.

\section{References}

1. Bentall H, De Bono A. A technique for complete replacement of the ascending aorta. Thorax. 1968;23:338-9.

2. Kouchoukos NT, Wareing TH, Murphy SF, Perrillo JB. Sixteen-year experience with aortic root replacement. Results of 172 operations. Ann Surg. 1991;214: 308-18; discussion 318-20.

3. Yacoub MH, Gehle P, Chandrasekaran V, Birks EJ, Child A, Radley-Smith R. Late results of a valve-preserving operation in patients with aneurysms of the ascending aorta and root. J Thorac Cardiovasc Surg. 1998;115:1080-90.

4. Cameron DE, Alejo DE, Patel ND, Nwakanma LU, Weiss ES, Vricella LA, et al. Aortic root replacement in 372 Marfan patients: evolution of operative repair over 30 years. Ann Thorac Surg. 2009;87:1344-9; discussion 1349-50.

5. Miller DC. Rationale and results of the Stanford modification of the David V reimplantation technique for valve-sparing aortic root replacement. J Thorac Cardiovasc Surg. 2015;149:112-4.

6. David TE, David CM, Manlhiot C, Colman J, Crean AM, Bradley T. Outcomes of aortic valve-sparing operations in Marfan syndrome. J Am Coll Cardiol. 2015; 66:1445-53.
7. Miller DC. Valve-sparing aortic root replacement in patients with the Marfan syndrome. J Thorac Cardiovasc Surg. 2003;125:773-8.

8. David TE, Feindel CM. An aortic valve-sparing operation for patients with aortic incompetence and aneurysm of the ascending aorta. J Thorac Cardiovasc Surg. 1992;103:617-21; discussion 22.

9. Gott VL, Greene PS, Alejo DE, Cameron DE, Naftel DC, Miller DC, et al. Replacement of the aortic root in patients with Marfan's syndrome. $N$ Engl J Med. 1999;340:1307-13.

10. Volguina IV, Miller DC, LeMaire SA, Palmero LC, Wang XL, Connolly HM, et al. Valve-sparing and valve-replacing techniques for aortic root replacement in patients with Marfan syndrome: analysis of early outcome. J Thorac Cardiovasc Surg. 2009;137:1124-32.

11. Stamou SC, Williams ML, Gunn TM, Hagberg RC, Lobdell KW Kouchoukos NT. Aortic root surgery in the United States: a report from the Society of Thoracic Surgeons database. J Thorac Cardiovasc Surg. 2015;149: 116-22.e4.

12. Coselli JS, Volguina IV, LeMaire SA, Sundt TM, Connolly HM, Stephens EH, et al. Early and 1-year outcomes of aortic root surgery in patients with Marfan syndrome: a prospective, multicenter, comparative study. J Thorac Cardiovasc Surg. 2014;147:1758-66. 1767.e1-4.

13. Benedetto U, Melina G, Takkenberg JJ, Roscitano A, Angeloni E, Sinatra R. Surgical management of aortic root disease in Marfan syndrome: a systematic review and meta-analysis. Heart. 2011;97:955-8.

14. Hu R, Wang Z, Wu HB, Wu Z, Zhou Z. Surgical reconstruction of aortic root in Marfan syndrome patients: a systematic review. J Heart Valve Dis. 2014;23: 473-83.

15. Song HK, Preiss LR, Maslen CL, Kroner B, Devereux RB, Roman MJ, et al Valve-sparing aortic root replacement in patients with Marfan syndrome enrolled in the National Registry of Genetically Triggered Thoracic Aortic Aneurysms and Cardiovascular Conditions. J Heart Valve Dis. 2014;23:292-8.

16. Svensson LG, Blackstone EH, Alsalihi M, Batizy LH, Roselli EE McCullough R, et al. Midterm results of David reimplantation in patients with connective tissue disorder. Ann Thorac Surg. 2013;95:555-62.

17. Schoenhoff FS, Langhammer B, Wustmann K, Reineke D, Kadner A, Carrel T Decision-making in aortic root surgery in Marfan syndrome: bleeding, thromboembolism and risk of reintervention after valve-sparing or mechanical aortic root replacement. Eur J Cardiothorac Surg. February 9, 2015 [Epub ahead of print].

18. Kari FA, Beyersdorf F, Rylski B, Stephens EH, Russe M, Siepe M. David I reimplantation procedure for aortic root replacement in Marfan patients: mediumterm outcome. Interact Cardiovasc Thorac Surg. 2014;19:743-8.

19. Ando M, Yamauchi H, Morota T, Taketani T, Shimada S, Nawata K, et al. Longterm outcome after the original and simple modified technique of valve-sparing aortic root reimplantation in Marfan-based population, David V University of Tokyo modification. J Cardiol. April 25, 2015 [Epub ahead of print].

20. Kvitting JP, Kari FA, Fischbein MP, Liang DH, Beraud AS, Stephens EH, et al David valve-sparing aortic root replacement: equivalent mid-term outcome for different valve types with or without connective tissue disorder. J Thorac Cardiovasc Surg. 2013;145:117-26. 27.e1-5; discussion 126-7. 